\title{
ローカル・エリア・ネットワークによる
}

紙試験データ処理システム

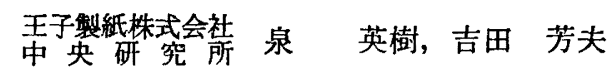

\section{A Data Processing system for Paper Testing Utilising Local Area Network (LAN)}

\author{
Hideki Izumi and Yoshio Yoshida \\ Central Research Laboratory, Oji Paper Co., Ltd.
}

\begin{abstract}
A data processing system for paper testing utilising local area network (LAN) has been developed as a part of laboratory automation program. The system consists of paper testing instruments, personal computers, and a LAN network. Testing results are made into a report by communicating data between instruments and computers, and between computers.
\end{abstract}

Keywords: Paper testing, Data processing, Local area network, Laboratory automation, Computer

\section{1. はじめに}

現在, 各種の紙陚験自動化システムが市眅されてい るが, 当所では LA (Laboratory Automation)の一 環として独自に紙試験データ処理の自動化に取組んで 来た。

今回, LAN (Local Area Network) を導入するこ とにより所期の目的を满足するシステムを開発したの でここに御紹介させていただく。

このシステムは紙試験機，パソコン，LAN で構成 されており，紙試験機とパソコン間及びパソコン相互 間のデータ通信をLANで行い, 試験報告書を作成す
るものである。

\section{2. 開発の目的}

紙試験の作業は次の 2 種類に大別できる。

(1) 陚料を調湿し陚験に合った寸法に切って陚験機で 測定する作業

(2) この測定値から平均値等を計算し，試験表及び武 験報告害を作成する作業

開発に当たり，次の制約条件があったので，大きい 試料寸法が必要となる(1)作業の自動化をあきらめ, (2の作業を自動化することとした。自動化の具体的な 目標を表 1 に示す。

表 1 自動化の目標

\begin{tabular}{|c|c|c|}
\hline 項 & 従 来 の 方 法 & 自 怔 化 の 目 標 \\
\hline データの読取り & $\begin{array}{l}\text { 試験機から目で読取りノート } \\
\text { に記入する }\end{array}$ & $\begin{array}{l}\text { 試験機とパソコンをオンライン化し, データをパソコン } \\
\text { へ直接入カする }\end{array}$ \\
\hline 平均値等の計算 & 電卓で計算する & パソコンが計算する \\
\hline $\begin{array}{l}\text { 試験表及び試験 } \\
\text { 報告書の作成 }\end{array}$ & $\begin{array}{l}\text { 手書き又は，ワープロで作成 } \\
\text { する }\end{array}$ & 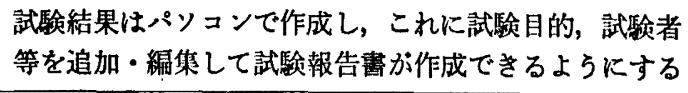 \\
\hline
\end{tabular}


<制約条件 $>$

-中央研の紙試験業務の実情に合ったシステムである こと。工場の場合は紙寸法に制約は無いが，中央研 の場合は紙寸法の小さい試料が比較的多く，紙寸法 が限定される。

・現在使用している紙試験機ができるだけ活用できる こと。

・試験者が使い易いこと。

\section{3. 開発の経過}

本システムは次の 3 段階のステップを踏んで開発し た。

3.1 第1ステップ（パソコンによる試験表作成 プログラムの閒袠）

試験の生データをパソコンヘ手で入力すれば，パソ コンが平均值を計算し，試験表を作成するプログラム を開発した。

現在は，これに相当するソフトが市肘されているが， 当時は無かったので BASIC でプログラムを組上け゚た。

\section{2 第 2ステップ（試験機とパソコンのオン} ライン化)

試験データを試験機からパソコンヘ直接入力できる ようにするため, 試験機とパソコンを標準インターフ ェイスである GPIB (General Purpose Interface Bus）又は，RS-232C で接続し，試験機とパソコンの オンライン化を実施した。

パソコンに接続出来る試験機の台数には制限（1 ポ ート当たり GPIB で最大 14 台， RS-232C で 1 台） があるため, 紙武験室では合計 4 台（当時）のパソコ ンを使用して各種試験機のデータを入力していた。 陚駼表を作成するためには，データを 1 台のパソコ ソへ集める必要があるので，フロッピーディスクを介 してオフラインでデータを集め,これに 3.1 で開発し たプログラムを適用して試験表が作成できるよらにし た。

\section{3 第 3 ステップ（LAN の藏入）}

試験機とパソコン間，パソコンとパソコン間のデー タ通信ができ LAN を導入し，複数のパソコンに入 カされたデータをオンラインで 1 台のパソコンへ集め ることができるようにした。これらのデータは LAN に接続しているパソコンなら，どのパンコンからでも 呼出すことがでさるので，任意のパソコンでデータを 呼出すことができる。

市販の統合型ソフトを用いて呼出したデータから陚 験表を作成し，更に試験年月日，陚験者，陚験目的， 武験条件等を追加・編集して武験報告書を作成できる
よらにした。

\section{LANによる紙試験データ処理 システムの概要}

\subsection{LAN の選定}

LAN は Local Area Network の略で，数キロメ 一トル程度の限定された地域内に抹けるネットワーク （通信網）と定義されて扣り，大型コンピュータ，プ ログラム，プリンタ，データベース，ファイル等資源 の共有を主な目的として使う場合が多い。

LANのメーカーを大別すると，LAN 専門メ一カー とコンピュータ・メーカーに分けることができる。当 所では, LAN 南門メーカーであるフンガマン・バス 物の Net/One を選んた。そその選定理由は次の通りで ある。

(1) IBM，日本䉓気，富士通など，異なったメーカー の情報処理機器 (ニンピュータ等) 間の相互通信が 可能である。従って，情報処理機器を自由に選択し， 柔軟性のあるシステムを構筑することがでさる。

(2) 伝送媒体として，同軸ヶーブル及び光ファイバー の両方が使える。

(3) LAN の世界的な標準仕様であるイーサネット・ ベースパンド方式 (IEEE 802.3) 及びイーサネッ ト・ブロードバンド方式 (IEEE 802.3)，トークン・ 泣方式 (IEEE 802.4)，トークン・リング方式 （IEEE 802.5）を採用して和り抎張性が高い。

(4) パージョンアップ（機能向上）等の变更に対して 柔軟に対応できる。

(5) 保守・管理が容易である。

(6) 世界中の企業, 大学, 研究所, 病院等で広く採用 されており信頼性が高い。

\section{2 紲試驗データ処理システム}

紙試験データ処理システム(以下，システムと略す) は試験機，パソコン，LAN で構成されており，その 概念図を図 1 に示す。

\section{2 .1 試 聒 機}

このシステムには，陚験データを電気信号として出 力でさる試験機しか接続できない。しかし，現在の試 験機はほとんどが電気信号を出力できるようになって おり，必要ならば若干の改造を施すことによりオンラ イン化が可能となっている。

1）オンライン化した陚験機

-GPIB インターフェイス付き陚験機（パソコン 4 K 接続)

天作

ガーレーこわさ計 


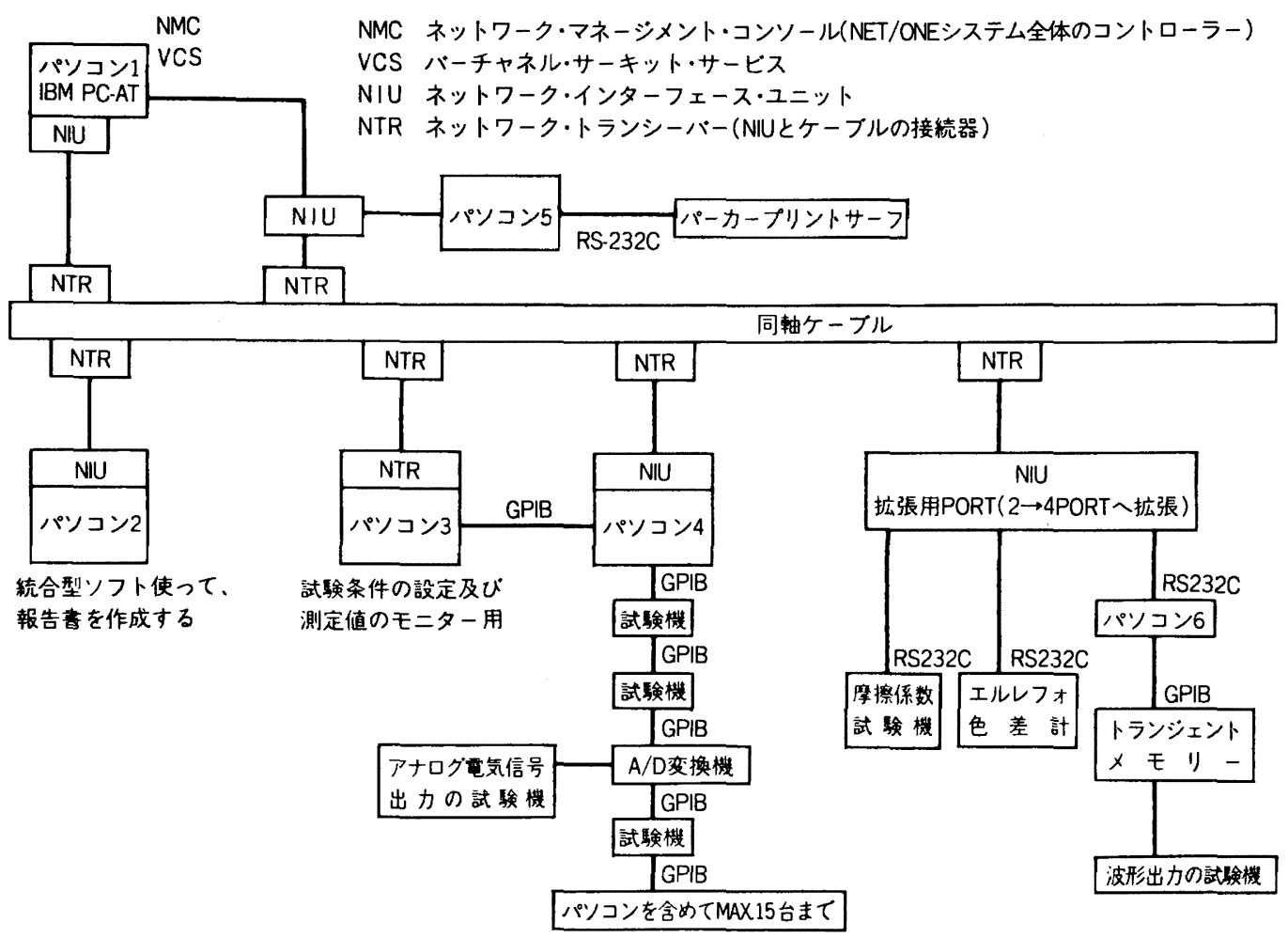

図 1 LAN による紙試験データ処理システムの概念図

エルメンドルフ引裂き試験機

$\mathrm{KBB}$ サイズ度試験機

MIT 耐折試験機

超音波伝播速度計

厚さ計

- RS-232C インターフェイス付き試験機 (パソコン 5

又は NIU に接続）

パーカーブリントサーフ平滑度計

摩擦係数試呀機

エルレフォ色差計

・アナログ電気信号出力の試験機 (A/D 変換機で GPIB 出力とし, パソコン 4 K接続）

ハンター白色度試験機

光沢度計

王研式平滑度透気度試駼機

破裂試験機

・波形データ出力の試験機（パソコン6に接続） テンシロン引張試験機

連続厚さ計

表面粗さ計
2）オンライン化していない試験機

クラークこわさ計

テーバーこわさ計

ベック平滑度試験機

ガーレー透気度試験機

4.2 .2 パソコン

ヘパソコン 1 : 次章参照

・パソコン 2 : パソコン $1,3 \sim 6$ は 3 階の紙試験室 に設置してあるが，このパソコン 2 は 2 階の居室に 設䓥してある。主に, 試験報告畫の作成及び試験機 とパソコンがオンライン化されていない試験データ の入力等に使用する。

•パソコン $3,4,5$ : パソコン 4 は GPIB, パソコ ン 5は RS-232C インターフェイス付き試験機と接 絖している。これら試呤機のデータは試験機に付属 しているボタンを押すことにより，パソコンへ入力 することが出来る。パソコン 3 は GPIBインターフ エイス付き試験機の条件設定用（陚料数，試験項目， 試験回数等の設定) に使用している。

・パソコン 6 : 引張り試験機, 表面粗さ試験機, 連続 
厚さ試験機等波形データを出力する試験機と接続し ている。これら試験機の波形データはこのパソコン で解析する。

パソコン $3 \sim 6$ の試験データは LAN でパソコン 1

へ送られ，ハードディスクに保管される。

\subsubsection{LAN}

Net/One のハードウェア及びンフトウェアの機能 は次の通りである。

- NMC : Network Management Console の略。 NMC はシステム全体をコントロールする機能を持 ってお゙り, NMC としてパソコン1 (IBM のパソコ ン PC-AT) を使用している。システムを立ち上げ る場合，まずパソコン1に入っている NMC のソフ トを NIUに移す。これでシステムは稼働状態にな る。

-VCS : Virtual Circuit Service の略。データ通信 する相手を決めるためのソフト。パソコン1に入っ ており，NMC と同様に NIU に移されて機能する。 ・パンンン1：システムを立ちあげる際に必要なパソ コソで, NMC 及び VCS のソフトがこのパソコン に入っている。このソフトは NIU に電源を入れる とパソコン 1 から自動的に NIU に移され, システ ムは稼働状態になる。このパソコンはソフトをNIU に移した後（システムが稼働しているとき）は通常 のパソコンとしても使らことができるし，システム
の稼働状況をモニターをすることもできる。 パソコン 2 ～ 6 のデータは全てこのパソコンK保管 することができる。

-NIU : Network Interface Unit の略。試験機やパ ソコンがデータ通信する際のインターフェイスてあ る。データは全てこの NIU を通して伝達される。 NIU は NMC 及び VCS のソフトをパソコン 1 か ら移されてはじめて機能する。NIU には BOX 型 と BOAD 型があるが，その機能はほとんど同じで ある。

•NTR : 同軸ケーブルと NIU 間でのデータのやり取 を行らトランシーバー。

・同軸ケープル：ネットワークの媒体。データはこの ケーブルを経由して通信される。

\section{3 紲試験から試験報告至作成までの操作手順}

1) 紙試験の操作手順

(1) 試料を調湿し，陚験に合った寸法に切り，試験機 で測定できるよらにする。

(2) パソコンで試験条件を設定する。

・試験コード No. を入力する。

・試験項目が表示されるので，試験する項目の No.を 入力する。

-試料数, 测定面 (表裹), 測定方向 (縦横), 測定回 数を入力する。

(3)これから测定する試験項目を入力し, 試験を行う。

表 2 紙試験の自動化システム

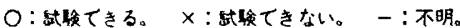

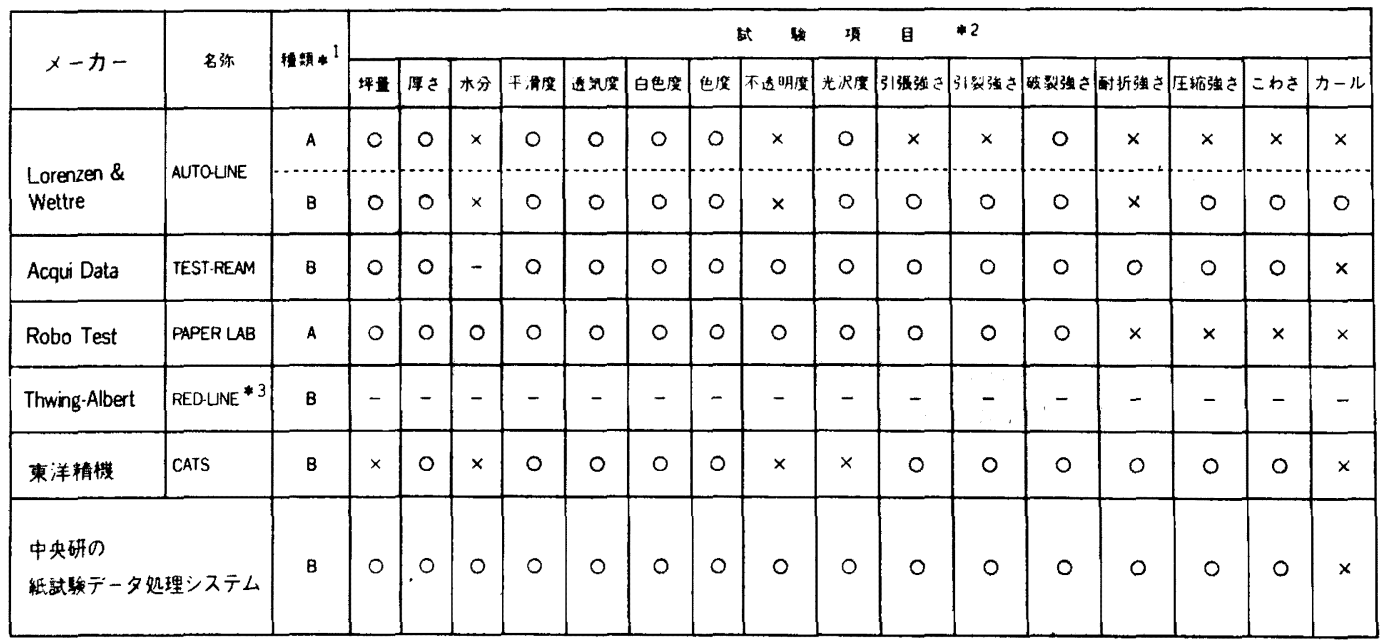

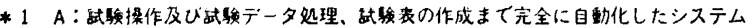

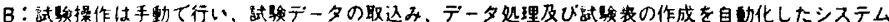

*2 カタロク、取扱い错明室から引用

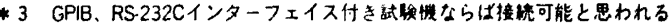


表 3 紙試験自動化システムの種類と特徵

\begin{tabular}{|c|c|c|}
\hline システムの種類 & A & B \\
\hline システムの名称 & $\begin{array}{l}\text { AUTO-LINE (Lorenzen \& Wettre) } \\
\text { PAPER LAB (Robo Test) }\end{array}$ & $\begin{array}{l}\text { AUTO-LINE (Lorenzen \& Wettre) } \\
\text { TEST-REAM (Acqui Data) } \\
\text { RED-LINE (Thwing Albert) } \\
\text { CATS (東洋精機) }\end{array}$ \\
\hline 省力化の効果 & 大きい & 中位 \\
\hline 試 料 寸 法 & 一定の大きさが必要 & 小さくても可能 \\
\hline 試 験 法 & $\begin{array}{l}\text { 外国の製品なので JIS に合わない試験法も } \\
\text { ある }\end{array}$ & 外国の製品は JIS K合わない陚験法もある \\
\hline
\end{tabular}

試験 1 回毎にデータを確認しながら，転送ボタンを 押しデータをパソヌンへ入力する。データはパソコ ソに画面表示される。

(4) (3)を繰返し, 全部の試験を行う。

(5) データをパソュン1へ送る。

2) 試験報告書の作成

報告書の作成はどのパソコンでも可能であるが，主 にパソコン2で行っている。

まず，パソコン 1 に入れてある市眅の統合型ソフト を呼出す。次に，データを呼出して陚験表を作成し， これに試験年月日, 試験者, 試験目的, 試験条件等を 追加・鼠集して報告書を作成する。

\section{4 システムの位量付け}

紙試伢の自動化システムは試験機メーカーから各種 発表されている。その概要を表 2 に示す。

紙試験の自動化システムを大別すると次の 2 種類に 分けられる。

$\mathrm{A}$ : 紙試検の操作及び試験データ処理, 試験表の作 成まで完全に自動化したもの

B : 試鏂データ処理, 試験表の作成を自動化したも の

これらシステムの特改を表 3 に示す。

当所で開発したシステムはBの試験データの処理だ けを自動化したものであり，紙試験の操作は自動化さ れていない。しかし，試験データの処理は完全に自動 化されており，システムの柔䎶性も高い。例えば，才 ソライン化されていない試験機の測定值はオフライン で入力させて, 他の試験項目と一緒に試験表を作るこ とがでさる。また，新らしい試験機が設固された場合， 容易にこのシステムに組入れることが可能である。
ここで，本システム稼働によるメリットを見ると次 の通りである。

-正確度の向上 : データの読取り, 計算, 報告書作成 における転記ミスが無くなる。また, データの異常 值はハララッキの大きさで判断できる。

-省力化: 試料種類, 試験項目及び測定回数の多少で 変化する。多い方が省力化は大きい20～30\%の省 力化が期待できる。

\section{5. 今後の発展と課題}

紙試験データ処理システムを完成させるために LAN を導入したが,ここに導入した LAN (Net/ One）は汎用性があり, 研究所の自動化 (LA)を進め る際には，中心的な役割を果するのと期待している。 図2に Net/One の抁張例を示す。図において, Phase Iはパソコン中心の LAN。Phase II は, ホスト・コ ンピュータ及びミニコン等を接続してネットワークを 払張した例。Phase III は更に，巽なる方式の LAN と 接続し，オフィスと工場を結んで広域 LAN に払張し た例である。

今後の梁題としては,

(1) 中央研究所と本社, 工場とのデータ通信

(2) ミニコンピェータまたは大型コンピュータと接

続しデータバンクとしての利用払大

等が考えられる。必要性に応じてこれらの課題に取組 んでいく予定である。

\section{䪭 辞}

Net/One に関する資料をご提供いただいたアンガ マン・ハスス株式会社 佐藤一雄氏に深く感謝致します。 


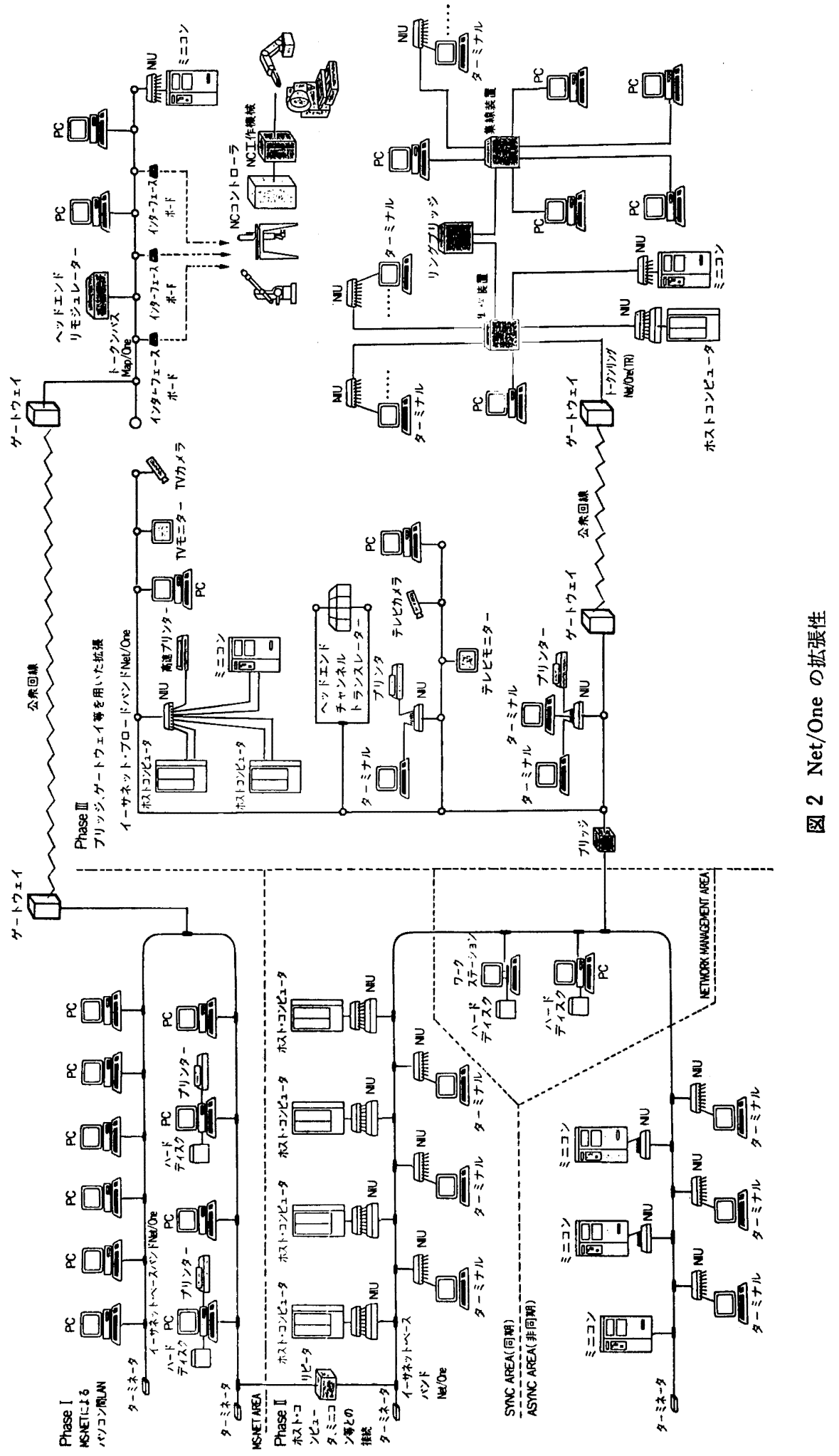

